\title{
est- patches
}

\section{test-patches}

\section{渡邊 淳司* \\ Mar i a Adr i ana Ver daasdonk** \\ cel I /66b*** \\ Junji WATANABE \\ Maria Adriana Verdaasdonk \\ cel I /66b}
* 東京大学大学院 情報理工学系研究科 j unj $i$ @ tar.t.u-tokyo. ac.jp
** Perfor mance uni t 66b
*** Medi a Perf or mance uni t cel l /66b
mari ana@i si on.co.j p
cel I @moncaf e.co.jp

\begin{abstract}
概要ｃell//66b はモノクロの単純な幾何図形の映像とリズムを作り出すためだけの音をダンスに 付与し，ステージを構成してきた。これは表現という行為において観察者のイメージ , 価値観を想 起させるための最小限かつ本質的な部分を抽出した結果である . 舞台に多くの複雑な情報を付与で きるようになった現在において , 敢えてモノクロの幾何図形の映像及びリズム音のみの音楽を使用 することによって，パフォーミングアートにおける身体と映像・音楽の関係性を問い直している．
\end{abstract}

\begin{abstract}
Media performance unit cell/66b uses real time computer graphics and animation, expanding the performing potential of the human body in a festival of light and sound. The relationship of the performing bodies with visual imagery and soundscape, becomes an ever-shifting dynamics. In the "test-patches", cell/66b uses monochrome images and simple sounds related to the essence of body movements to enhance dancers' power of expression. Currently, the author and cell/66b are developing devices, which can synchronize body gesture to the visual and sound network.
\end{abstract}

キーワード： パフォーミングアート，インターフェイス，ウェアラブル , 同期 , MIDI

Keywords : Art, Performance, Interface, Wearable, Synchronization, MIDI

1. はじめに

近年，コンピュータグラフィックス等の映像をダンスに付与 して舞台が構成されるようになった．また，コンピュータの性 能が上がるにつれ，複杂倠な映像を多く，同時に付与することも 可能となった[ 1] [ 2] [ 3] [4] [5] [6] .しかし，より複雑な情報を ダンスに対して付与できるようになったとしても，弚れがひと つの表現として成立していなければ，アートとして光こに映像 を付与する意義は存在しない .

\section{2 . cell/66b}

cell/66b のパフォーマンスにおいては, ダンスの他にモノクロ の幾何図形の映像と単純なリズム音のみを使用して舞台は構成 されている．単純な映像とリズム音という，乥れぞれ要素だけ を見ると表現としては成立し得ないが , パフォーマーの身体運 動と適切に結びつくことにより，光こに新たな関係性が生まれ， 観察者のイメージの想起を促進する . cell/66b は光れぞれのモー ダルのミニマル化とともにモーダル間に関係性を作り上げてい くことをテーマとして , パフォーミングアートにおける表現の 可能性を探っている.

cell/66b の舞台は全体でひとつのストーリーを持つものではな く，乥れ光れが完結するいくつかのシーンで構成されている. 各々のシーンはメンバーが何らかの実験的意図を持って持ち込 んだ断片(test patch)であり，各々のシーンごとにテーマが存 在する. 光して，光の全体を「t est-pat ches」と呼ぶ．

シーンにおいてはパフォーマー及び背後のスクリーンに対し て，プロジェクターで映像を投影することによってパフォーマ
一の身体表現を強化する . パフォーマーの衣装は全て白もしく は黑であり，ある時はパフォーマー自体がスクリーンとなり映 像に立体感を生み出すとともに, またある時は , パフォーマーは 黑い影となってステージから消滅する．

例えば, シーン「Genki Penki」では, 白い衣装を着たパフォ ーマーに対して映像を使ってリアルタイムに絵を描いていく. これは, 舞台上で繰り広げられるパフォーマーと映像作成者の セッションであり，パフォーマーの動きによって映像作成者は 描く絵を変化させ, また, パフォーマーは知覚される光の変化 によって自身の動きを変化させる．

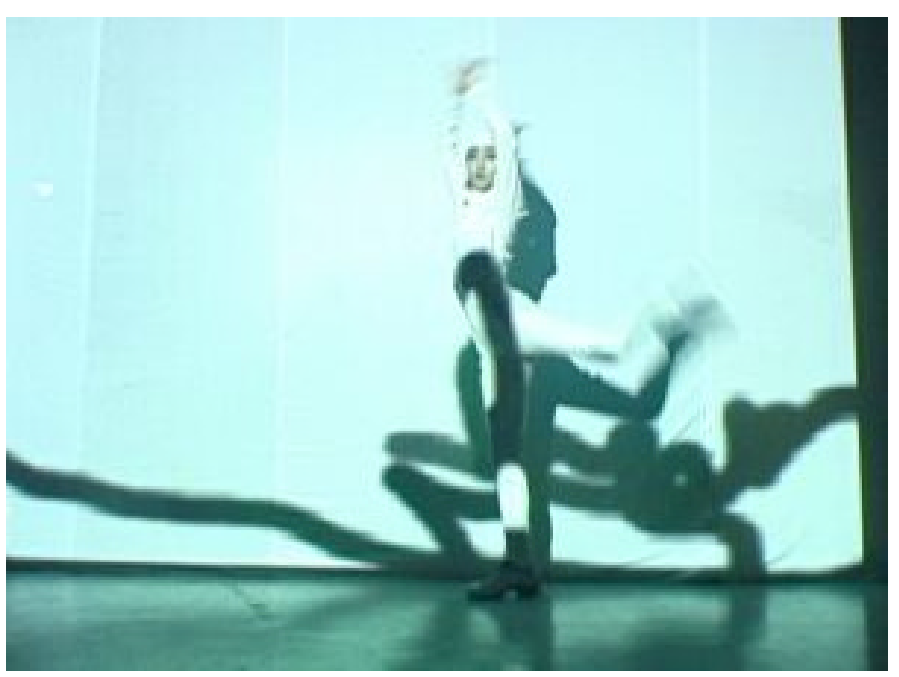

図 1 シーン $\ulcorner$ Genki Penki」 
3. cell/66b with devices

筆者と cell/66b は身体と映像・音楽の関係性というコンセプト をさらに進め，ダンサーの動きを映像及び音楽に直接反映させ るデバイスを開発して作品を構成している．具体的には，図 2 に示すようにデバイスで計測したパフォーマーの身体運動を MIDI 信号に変換して, 映像及び音楽システムへ入力する . 映像 システムは Genemagic (http://www.genemagic.com/)の MIDI 信号 で駆動されるリアルタイムレンダリンググラフィックソフト cVA を使用している.cVA はあらかじ作られた映像エフェクけパ ラメータ 例えば,移動エフェクトにおける移動量等)を MIDI 信号によ ってリアルタイムに変化させることが可能である.音楽システムは CYCLING'74社( http://www.cycling74.com/) のMAX/MSP を使用 している. 電子楽器の共通言語である MIDI 信号を使用すること によって, 身体運動, 映像, 音楽の全てがお互い影響を及ぼし 合うことが可能となっている

シーン「Signal」では図 3 のように白い衣装を着たパフォーマ 一(図中央) に対して，ある奥行き構造を持った映像を付与して いる . パフォーマーが踊っている間はパフォーマー自身の身体 及び運動の立体感を映像によって強化する一方, ダンサーの静 止とともにダンサーの身体はスクリーンの一部となり消滅する ことになる .このシーンでは, 立方体のモデルに対して格子模 樣のテクスチャが貼り付けられており, パフォーマーの背中に 装着されたのジャイロセンサからの值によって立方体モデルの 横幅，縦幅，奥行きが変化する．また，このシーンでは特に観 察者の感じる奥行き感に焦点を当てている . パフォーマーの身 体が存在する奥行き位置とスクリーンの奥行き位置，さらには 映し出される映像の中の奥行きというようにこのシーンの中に は少なくとも3つの奥行きが存在する . 観察者はこの全ての奥

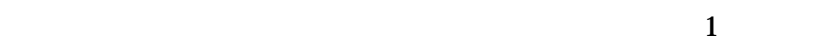
意を向けては他の部分へ注意を移すということを繰り返す．こ のとき，身体運動を計測することにより，激しい動作によって 身体の存在が観察者に意識されるのに合わせて背後の奥行き構 造を大きく变化させることも可能である. また逆に身体が静止 するとともに背後の奥行き構造を大きく変化させることによっ て身体と映像のコントラストを創り出すことも可能である

図 4のシーン「Liquid Dream」では, 右側のパフォーマーの手 にジャイロセンサが装着され , パフォーマーの手の動きに合わ せて背後の波面の中心(図 4 中央)が移動する . また , パフォーマ 一はジャイロの值を MIDI 信号に変換するかどうかをオンオフ可 能であり，常に手の動きに合わせて波面が変化するわけではな く，パフォーマー側の呼吸に合わせて波面は構成される.さら にこのとき, ジャイロの值をすぐに MIDI 信号に変換して映像を 变化させるのではなく, ある一定の遅れを入れることで不安定 な関係をパフォーマーの動きと波面のあいだに構築し，光こに 観察者のイメージが入り込む余地，つまりは観察者の側が身体 と映像の関係を想像し，観察者の側で何らかの関係を意識する 余地を作っている.また , このシーンでは 2 人のパフォーマー に対してセンサを装着することも可能であり，この場合，2つ の波面の中心が 2 人のパフォーマーのユニゾン (タイミングの 同期したダンス) に合わせて動くことによって，ステージ上に 身体と映像の 2 つニン゙ンを創り出すことも可能である．
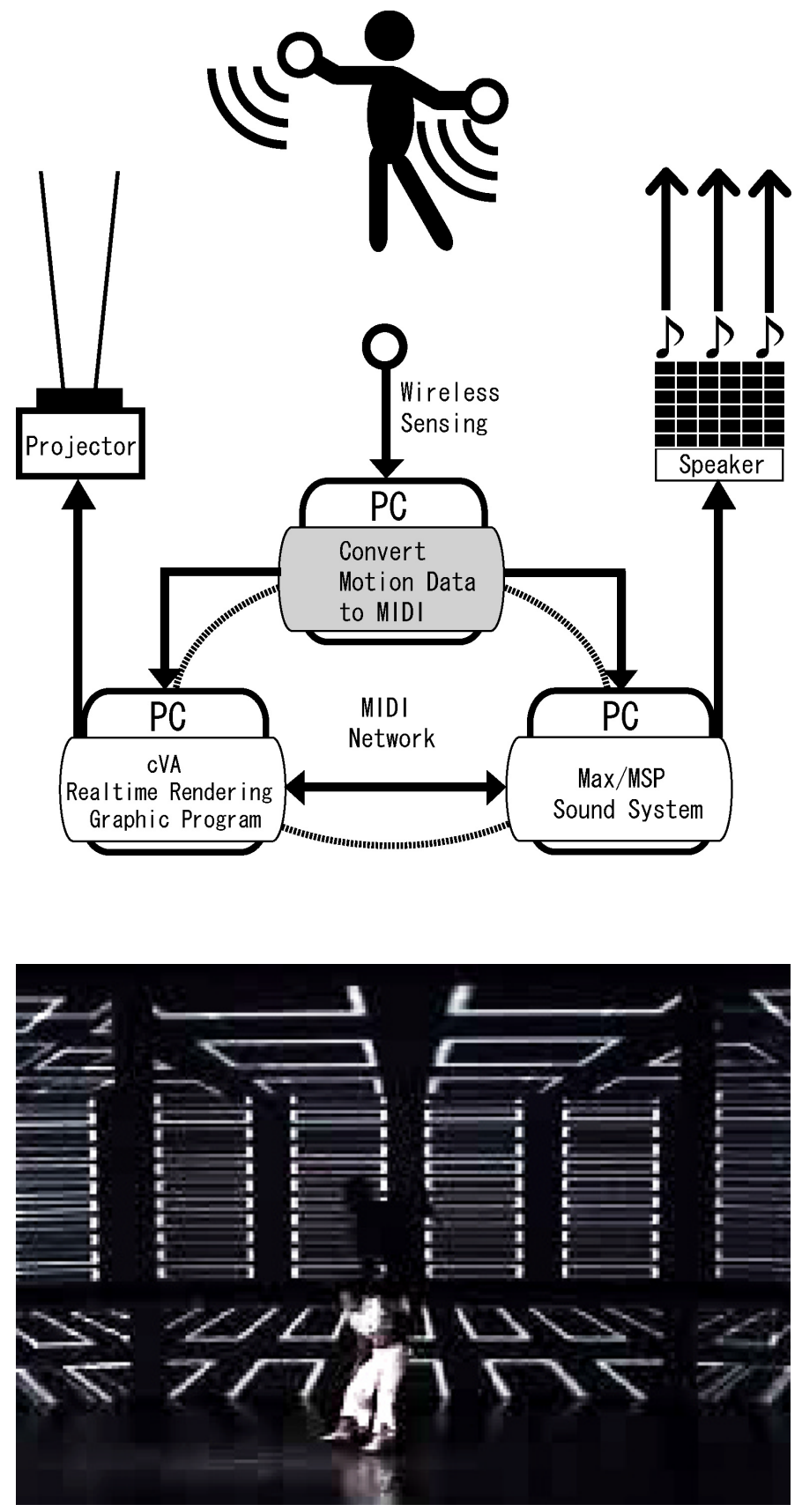

図 3 シーン「Signal」

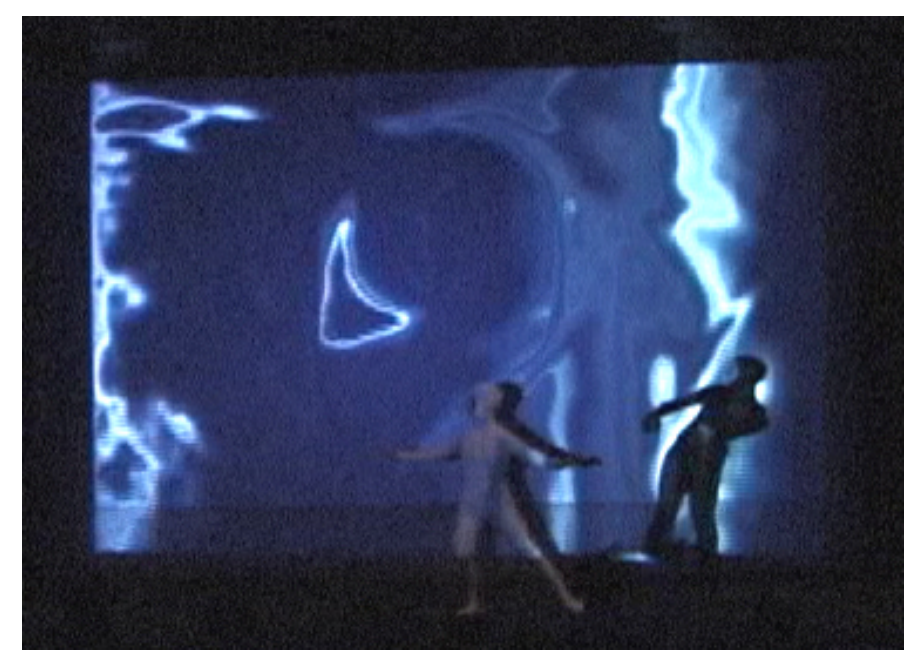

図 4 シーン $\ulcorner\mathrm{Li}$ qui d Dream」 


\section{5 . 身体運動の变換について}

デバイスを使用したシーンでは，身体運動と映像・音楽をど のように関係付ければ表現として成立し得るのかが重要となる ただ単に明示的に光の関係性を示すことは必ずしもパフォーマ 一の表現能力の拡大に䌘がるわけではなく, 強い関係性よりも , 因果関係が微かにわかるが, 弚の結果は予想できない程度の弱 い関係性のほうが，観察者とってイメージをより想起させる表 現になることも多い[7]．また, 当然ながら, 観察者の側の知識 や専門分野によってどのように関係付けを行えば最もイメージ を想起させる表現となるかは異なる．デバイスの装着を知らな い観察者にとって，身体運動と映像の強い同期は，兰の関係性 に気付き，なんらかのイメージを想起し始めるきっかけとなる しかし，あまりにも強い関係性はデバイスの装着を知っている 観察者にとって , デバイスのデモンストレーションになりかね ない，乥の関係性を決定することは非常に困難ではあるが，例 えば, シーンの初めに観察者が気付く程度に関係性を強くした り，関係性を強調した数秒のシーンを入れることによって，観 察者が兴の関係性についてイメージを想起し始めるトリガーと し，乥の後は説明的にならないように関係性を弱めていくとい う演出方法も存在する．

また，このシステムをパフォーマー側から考えると，パフォ ーマーは自分の動きによってステージ全体の映像や音楽に影響 を与えるとともに，人の手では作ろうとしても不可能な微妙な 変化を含んだ表現を行うことが可能となる . パフォーマーにと ってデバイスの装着は表現能力の拡大を意味する一方で, パフ オーマーは自身の動きから創り出されるステージ全体に広がっ た映像や音楽を感じ取り，光こから新たな表現を生み出す能力 が必要とされる．より広い空間，より細かい光や音楽に対する 感受性が求められ，㚇のフィードバックを感じ取ることができ るパフォーマーのみが予定調和でない新たな表現を生み出すこ とができる .

$$
\text { 5.まとめ }
$$

cell/66b は身体運動とミニマル化された映像・音楽の関係性を コンセプトとして表現を構成している．さらに，筆者らは身体 表現における本質的な部分を抽出，拡大するためにデバイスを 利用してシーンを構成した .デバイスを利用する上で重要とな るのは身体運動と映像及び音楽をどのように関係付けるか [ 8] [ 9] [ 10] [ 11] ということであり，これまでの人間の知覚研究 [12]とは逆の流れに着目したものである．本作品「testpat ches」は身体と映像・音楽の関係性に対する, 各シーン作者 のイメージをもとに構成されたものである．筆者は身体及び映 像・音楽との関係性を，デバイスを利用することによってシー ンとして具現化し，弚の関係性のあり方を考察した．今後はデ バイスという視点をより深めて表現と技術のあり方を考えてい きたい，例えば，デバイスを使用しないと成立し得ないシーン を構成する一方で、弚のシーンにおいてどれだけデバイスのデ モンストレーションにならない表現が可能か．具体的には指先 の曲げや重心移動等，見えないような小さな運動を拡張してス テージ上に映像や音楽として表出させるシーンや，床を踏みつ ける現実の音とデバイスによって創り出される音が重なり合う シーン等でどのような表現が可能であるか考えていきたい．

\section{参考文献}

[1]cell/66b:"test- patches", http://www.vision.co.jp/66b/ (Jul. 31 2002).

[2]dumb type : "dumb type ", http://dt.ntticc.or.jp/ (Jul. 31 2002).

[3]Leni- Basso:"Leni- Basso", http://www.kk.iij4u.or.jp/[ wildhany/leni.htm(Jul. 31 2002). [4]nest: "NestTV.com", http://wnw.kt.rim.or.jp/[ nesst (Jul. 31 2002). [5]Michel Lemieux / Victor Pilon :"4D art", http://www.4dart.com/4Dart.html/en/menu.html/ (Jul. 31 2002). [6]河口洋一郎:"GEMOTION", http://www.race.u- tokyo.ac.jp/ $\square$ yoichiro/Jul. 31 2002). [7]平田オリザ: "演劇入門", 講談社, 1998.

[8]長嶋 洋一： "生体センサによる音楽表現の拡大と演奏表現の 支援について", 情報処理学会研究報告 Vol.98, No.74, 1998. [9]間瀬健二,フェルスライナース： "I amascope(インタラクティ ブ万華鏡) : グラフィックな楽器の提案", ビジュアルコンピュ ーティングとグラフィクス CADシンポジウム, pp. 91- 96, 1998. [10]岩舘祐一, 井上正之, 鈴木良太郎："身体動作からの感性特 徵量の抽出に関する検討", 映情学技報, Vol.24, No. 29, pp. 712, 2000 .

[11] 後藤 真孝, 村岡 洋一: "音楽に踊らされる CG ダンサーによ るインタラクティブパフォーマンス", コンピュータソフトウェ ア, Vol.14, No. 3, pp. 20-29, 1997.

[12]谷口高士: "音は心の中で音楽になる - 音楽心理学への招待", 北大路書房, 2000.

\section{* cell/66b MEMBER *}

Tetsu Tavata (media driver)

Mariana Adriana Verdaasdonk (conceptualiser/performer) Yui Kawaguchi (choreographer)

Natsuko Kinoshita (performer)

Era Kawamura (performer)

Kaoru Yamada (performer)

Hirotsugu Saegusa (performer)

Kyoichi Kita (performer)

Golden Suzuki (performer)

Junji Watanabe (device)

Nao Tokui (sound)

Kimken, Knoto, Mitsuru Kotaki (sound creators)

Hiroki Okushima (costume)

Mitsuhiro Matsuda (stage manager)

Gesho (stage)

*cell/66b 2002年 主な゙活動履歴*

·11/29-12/17 Global Media 2002 インスタレーション)，

東京都写真美術館, Tokyo, Japan

9/18 第 7 回日本バーチャルリアリテ学会大会, Tokyo, Japan.

-9/12,13,14 Jugendstil Theater, Vienna, Austria.

9/7,9 Ars Electronica Center, Linz, Austria.

8/29,30,31 Culture Center REX, Belgrade, Yugoslavia. 5/3 Next02, 東京都写真美術館, Tokyo, Japan. 